\title{
Self-Directed Learning Through Computer-Aided Mathematics Instruction: First-Year Teacher Education Experience
}

\author{
Folake Modupe Adelabu ${ }^{1}$, Abongile Ngwabe $^{1} \&$ Jogymol Alex $^{1}$ \\ ${ }^{1}$ Mathematics, Natural and consumer Sciences Education Department, Walter Sisulu University, South Africa \\ Correspondence: Folake Modupe Adelabu, Mathematics, Natural and consumer Sciences Education Department, \\ Walter Sisulu University, South Africa.
}

Received: October 20, 2021

Accepted: December 8, 2021

Online Published: December 9, 2021

doi:10.5430/ijhe.v11n3p79

URL: https://doi.org/10.5430/ijhe.v11n3p79

\begin{abstract}
Objective: The study investigates first-year teacher education students' self-directed learning through Computer-Aided Mathematics Instruction (CAMI).

Methods: A total of 230 first-year mathematics teachers specialising in Further Education and Training (FET) phase teaching participated in the study, where responses from 50 student teachers were purposively and conveniently selected to report on in this paper. A qualitative research method approach was used and open-ended questionnaires were utilised to collect the data for first-year teacher education students' self-directed learning. The questionnaires were analysed using descriptive data analysis.

Results: Results of the study revealed that CAMI was used to monitor students' learning, the time the learning takes place, the performance of the student within the duration of time, and to evaluate student performance. The results also revealed the skills that characterised self-directed learning and active learning where the student teachers were motivated to learn more and to solve difficult problems in mathematics.
\end{abstract}

Conclusions: The study recommends technology integration, such as CAMI, in teacher education and teaching and learning in the Higher Education Institutions (HEIs), to promote self-directed learning and support effective learning for future learners.

Keywords: computer-aided mathematics instruction, mathematical knowledge for teaching, self- directed learning, ICTs, mathematics education

\section{Introduction}

In this $21^{\text {st }}$ Century, teachers in the classroom are to engage in active learning so that there is an improvement in self-directed learning (Mthethwa, 2018). Many teachers stick to the same teaching methodologies and activities which were acquired during formal education without development of self-direction in learning (Ball, 2000). To empower teachers' education, the components of Self-Directed Learning (SDL) with regard to transferring knowledge need to be emphasized. Therefore, educators in Higher Education Institutions (HEIs) should not only transmit knowledge, but they should also provide guidance. In this regard, the prospective teachers in turn will be encouraged to guide the school learners in the future (Ben-Eliyahu \& Linnenbrink-Garcia, 2015; Bishara, 2021). In this regard, the educators should develop programs that increases the Self-Directed Learning (SDL) of the prospective teachers.

Research studies show that many mathematics teachers in South Africa found mathematics teaching very difficult, which leads to poor teaching practices in mathematics in the schools. Many mathematics teachers struggle to solve problems in some of the mathematics content of the curriculum, while many are not competent in the content knowledge of the subject (Sekano, 2020). Furthermore, South African mathematics classrooms are confronted with factors such as outdated teaching strategies, changes in the curriculum, lack of content knowledge and understanding, as well as motivation of teachers to take student performance to the next level (Sekano, 2020; Alex, 2019a). Other factors that confront mathematics in the classroom is teachers' inadequate SDL. All the factors resulted in poor learners' performance in mathematics. To develop the teachers' professionalism and to improve the learners' performance in mathematics, improvement in teacher education students' SDL through technology is required. Therefore, fostering mathematics content learning through technology, to create understanding and motivation in teacher education courses. 


\section{The research questions}

The research questions addressed in this paper are as follows:

- How does learning mathematics through CAMI enhance effective learning?

- To what extent does learning through CAMI influence first-year teacher education students' self-directed learning?

\section{Self-Directed Learning}

Self-Directed Learning (SDL) has the power to promote life-long learning, develop critical thinking, empower, and motivate learners, and can improve academic performance and professional competence. (Garrison, 1997) Garrison (1997, p. 2) defines SDL as an approach where learners are motivated to assume personal responsibility and collaborative control of their cognitive (self-monitoring) and contextual (self -management) processes in constructing and confirming meaningful and worthwhile learning outcomes.

According to (Van der Walt, 2016) the emphasis of SDL is on three aspects which are: self; self-directed; and learning. The self-emphasis refers to the distinctive personality and the awareness of individuality and existence. Learners in this study are referred to as first-year pre-service teachers. In this regard, self-directed learners (first-year pre-service teachers) exhibit interest, ideas, determination, autonomy, self-restraint, and self-motivation in learning (Van der Walt, 2016). Self-directed emphasis is on being directed and purposeful as well as the ability to control one's individual issues. This emphasis involves the management of individual learning by using activities to learn. For instance, learners (pre-service teachers) setting learning goals, and deciding on what to learn and how to learn a particular content. In addition, learners apply appropriate learning skills; strategies; and reflect on individual learning and the extent of achievement of their goals. Therefore, the self-directed pre-service teacher in this emphasis moves through the distinctive stages of management as in preparing, executing, observing, and assessing individual learning procedures which are based on consideration. (Bagheri, Ali, Abdullah \& Daud, 2013; Van der Walt, 2016). The learning emphasis is the process of mastering the learning material (CAMI). Self-Directed Learning (SDL) in this emphasis is a form of learning that is more difficult and thereby requires further engagement on the part of the learner (pre-service teacher). In other words, the learner should be actively engaged in learning, not just to be acquiring knowledge from the teachers without participation in the transmission of knowledge. The learner in this self-directed learning approach plays an active role in the learning process. The learner should be able to communicate effectively, cope with challenges and difficulties, as well as possesses problem-solving skills (Van der Walt, 2016).

Van der Walt (2016) argues that first-year students teacher education should possess a range of cognitive and meta-cognitive skills to enable them to embark on effective learning goals so that solving problems and effective evaluation could be accomplished. The reason is that the researcher discovered that many students do not have the skills and are not self-directed learners, which makes the transition to tertiary education difficult for them. (du Toit-Brits, 2020) acknowledges that the achievement of SDL within higher education institutions (HEIs) depends on the educator. The educator plays a central role in advocating SDL in the learning situation. Therefore, educators provide appropriate guidance to support students in participating actively in SDL activities. Furthermore, in a specific SDL classroom environment, the students have the responsibility of driving and navigating the learning process and experiences, complemented by the leadership of an educator as a self-directed student and SDL agent (Du Toit-Brits, 2020). Therefore, every educator aspires to develop a learning environment in HEIs that is favourable to SDL and to offer students uninterrupted support in learning to obtaining SDL skills (Du Toit-Brits, 2020).

According to (Makonye, 2016) SDL needs to be promoted in HEIs to enable the pre-service teachers to solve mathematics problems effectively. Kruger (2020) expresses the significant importance of SDL using technology because, in the environment, students will manage their own learning activities. Further, the above researcher concludes that SDL has the capability to measure, increase accuracy, increase learner performance, and connect with more students as characteristics of using technology in learning. Furthermore, (Jordaan \& Havenga, 2020) report in the study "University-school initiative for a career in engineering: development of self-directed learning when solving mathematics problems", that learners develop self-directed learning skills when introduced to solving mathematics problems. In addition, the investigation of blending and cooperating in the computer literacy classroom: an opportunity to develop self-directed learning skills by (Bailey \& Lubbe, 2020) reveals that educator enhances and equips pre-service teachers' SDL abilities in computer literacy by allowing them to assume responsibility with or without the assistance of other pre-service teachers. 
Hence, as proposed by (Mthethwa, 2018) first-year pre-service teachers should engage in active learning using CAMI which will enable the advancement of self-directed learning. Using CAMI, first year mathematics pre-service teachers should be able to:

- build-up the existing mathematical knowledge to teach;

- engage in active learning to teach rather than developing information to teach;

- handle and removing misconceptions about the concept;

- engage in authentic practical mathematics tasks;

- have opportunities to reflect on what has learnt;

- use formative assessment and provide constructive feedback regarding the learning progress (De Beer \& Gravett, 2016).

\section{Mathematical Knowledge for Teaching}

Built on the body of literature on the different types of teacher knowledge (Shulman, 1986; Ball, Thames \& Phelps, 2008) and (Pasley, 2011) as reported in (Alex, 2019a) that links with student learning, the terminology of 'Mathematical Knowledge for Teaching' of this paper will be represented as (MKfT) for the different types of knowledge that a mathematics teacher needs to have. Shulman (1986) included "the knowledge for the most regularly taught topics in one's subject area, the most useful forms of representation of those ideas, the most powerful analogies, illustrations, examples, explanations, and demonstrations-in a word, the ways of representing and formulating the subject that make it comprehensible to others" (p.9) within the category of Pedagogical Content Knowledge. One would understand that such knowledge should be imparted to the student teachers in their initial teacher training period. According to (Hill, Blunk, Charalambous, Lewis, Phelps, Sleep \& Ball, 2008) mathematical knowledge for teaching determines the subject matter knowledge that supports teaching in the classroom. Further, the above researchers explain that mathematical knowledge is that teachers should be able to develop knowledge of a specific mathematical procedures to be used in teaching. In addition, teachers should have the knowledge of the best way to define a mathematical term for the student and understand the types of errors students are likely to make with content being taught.

The theory of MKfT according to (Ball, Thames \& Phelps, 2008) and (Jacinto \& Jakobsen, 2020) comprises of six teachers' knowledge domains which are: common content knowledge (CCK), horizon content knowledge (HCK), specialised content knowledge (SCK), knowledge of content and students, knowledge of content and teaching and knowledge of content and curriculum. The CCK is defined as the mathematical knowledge frequently used in a diversity of situations, including outside teaching (Jacinto \& Jakobsen, 2020). CCK is knowledge that is closely associated with the content of the curriculum, but not to a particular curriculum. The teachers' knowledge includes knowing when students have wrong answers, recognizing when the textbook gives an incorrect definition, and being able to use terms and notation correctly during the teaching. It is the knowledge teachers need themselves to answer the assignment given to the students. It is common knowledge in teaching that students come up with non-standard methodologies that are not common to the teachers. Therefore, the teachers' knowledge is basically what teachers need to know and are able to do in order to come up with meaningful teaching methods (Ball, Thames \& Phelps, 2008). The HCK is the knowledge of 'how the content being taught is situated in and connected to the broader disciplinary territory' (Jacinto \& Jakobsen, 2020). The SCK is defined as 'the mathematical knowledge unique to the work of teaching'. Specialized Content Knowledge (SCK) is mathematical knowledge that does not require knowledge of students and a teacher's knowledge of teaching. The tasks of teaching in this knowledge requires substantial mathematical resources. Specifically, the teachers need to understand different interpretations of the concepts that are being taught in the classroom in such a way that students will understand. In addition, teachers should have the ability to present mathematical ideas during teaching and respond to students' questions at the same time. Furthermore, in this knowledge, teachers need to help students to learn and to unpack the elements of mathematics content to make it more understandable to the students (Ball, Thames \& Phelps, 2008).

The knowledge of content and students (KCS) is the combination of knowing about students and knowing about mathematics. Every task in this pedagogical content knowledge requires an interaction between a definite mathematical understanding and familiarity with students and their mathematical thinking. Knowledge of content and teaching (KCT) is the knowledge that combines knowing about teaching and knowing about mathematics. The mathematical tasks of teaching in this domain require mathematical knowledge that interacts with the design of teaching. Therefore, teachers need to structure a particular subject matter for teaching and determine which content to teach first. In addition, teachers need to understand the way the teaching will motivate the students in order to 
have deeper understanding of the content. Further, teachers need to assess the instructional benefits and drawbacks of representations used to teach a particular content.

Subject matter knowledge for teaching mathematical knowledge is a separate teachers' knowledge domain that is not twisted together with the knowledge of pedagogy, students, curriculum, or any other domains relevant to teaching. What distinguishes this mathematical knowledge from other knowledge of mathematics is that it is subject matter knowledge that teachers need for definite tasks of teaching. The tasks of teaching in this domain depend on mathematical knowledge. Specifically, the knowledge has a life that is comparatively independent of knowledge of students and of teaching. The required tasks in this domain are knowing how knowledge is produced and designed in the school and much more. These independent aspects of knowledge are skills and knowledge that are not typically acquired by the teachers through formal mathematical preparation courses. However, teachers engage in the mathematical practices themselves in order to teach and also learn to teach the concept to the students. The unambiguous knowledge and skill in these areas is essential for teaching (Ball, Thames \& Phelps, 2008). This paper looks at the subject matter knowledge of MKfT which is a combination of the three domains, namely; CCK, HCK and SCK acquired by first year student teachers in a HEI through CAMI.

\section{Integration of Computer Technology in Mathematics Education}

The concept of integration of technology refers to teachers and students making use of technology in teaching and learning. Integration of technology in education practices refers to the use of technology for student discovery, teacher-motivated design and sympathetic backing, effective use of computers for problem solving, and the comfortable use of the computer-based program for directed learning outcomes (Callaghan, Long, Van Es, Reich \& Rutherford, 2018). In this regard, technology contributes positively to teaching and learning both in the classroom and outside the classroom. In addition, integration of technology is related to self-motivated factors such as: active practices form of teaching and learning; high-tech aspects of the new tools; and potential learning transformation (Viberg, Grönlund \& Andersson, 2020).

The integration of technology in mathematics education plays a critical role and is increasingly developed as it is associated with good learner performance. In order for teachers to integrate technology in mathematics education they need to be technologically prepared in terms of knowledge and skills (Saylan, Onal \& Onal, 2018). Therefore, organized and effective learning requires a teacher to be proficient in the use of technological instruments and subject matter knowledge (Leung, 2017). Furthermore, in integrating technology in mathematics education, the teachers' professional development is required. In addition, the pre-service teachers' technological and pedagogical content knowledge needs to be developed. Therefore, the use of technology should be entrenched in a logical educational context (Viberg, Grönlund \& Andersson, 2020). The integration of technology in mathematics education has several benefits. According to (Bray \& Tangney, 2017) technology opens various ways for students to construct and engage with mathematical knowledge, sets the subject (mathematics) in true and reliable frameworks, and simplifies the concept activity in a meaningful way to the students. Furthermore, technology increases teamwork and emphasises more on practical applications of mathematics, through modelling, visualisation, manipulation, as well introduces multifaceted developments in teaching and learning. In addition, technology develops a collaborative and explorative classroom as well as increases problem-solving and inquiry-based learning rather than memorisation of facts and procedures (Bray \& Tangney, 2017).

Nowadays, a self-directed approach to learning the content the student teachers need to deliver to their future learners through the integration of technology is a necessity. SDL was established through the CAMI program with its structured and sequenced exercises, speed notes, grading procedures, evaluation, and feedback in each question in the Mathematics Education and Research Centre in a HEI in South Africa. By incorporating the concepts of; Self-Directed Learning, Mathematical Knowledge for Teaching, and Integration of Computer Technologies in the teaching and learning processes, the following model developed by the founder of the Centre was piloted. The model is shown in Figure 1. 


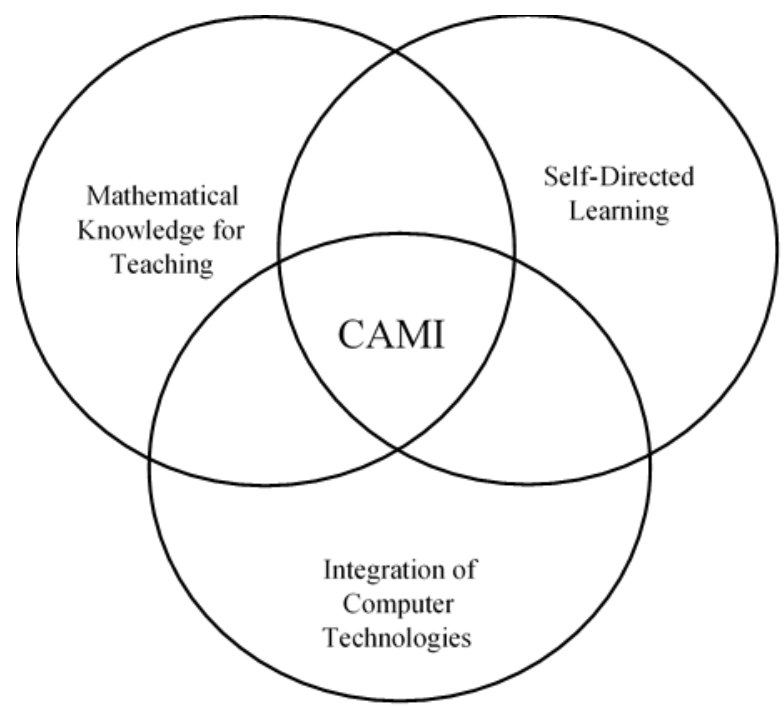

Figure 1. A Model for Pre- Service Mathematics Teaching (Alex, 2019b)

\section{Methods}

The Mathematics Education and Research Centre at a HEI in the Eastern Cape Province, South Africa, was established from a strong desire to develop the mathematical competencies of the mathematics education student teachers. Concerned by the matric passe rate in the area and the fact that it is linked to teaching methods and the subject content knowledge of the teachers (Alex, 2019a), the founder of the centre piloted the new model for teaching pre-service mathematics teachers in the HEI. The Centre is subscribed to a licensed on-line CAMI program. In consultation with the lecturer in charge of the first-year students, a topic that was not previously taught (Probability) was selected to pilot in the Centre. A lab assistant and two lecturers in the Centre monitored the processes of Probability Learning through CAMI. Instructions and illustrations to complete the exercises were explained and pasted in the Centre.

\section{Participants and sampling}

A total of 230 first-year mathematics student teachers who specialise in Further Education and Training (FET) phase teaching participated in the study. From these participants, a sample of 100 student teachers were selected using purposive and convenience sampling to report for this paper. The student teachers were exposed to technology-based (CAMI) learning at the university level in preparation for future teaching and learning. During the study, the student teachers were given two weeks to complete 25 exercises with 300 questions in Probability built within the CAMI. The student teachers were instructed to complete the following exercises on Probability with its subsections through self-directed learning: Introduction to Probability, Conditional Probability, Probability Models, Venn Diagrams and Binomial Probability. Thereafter, the participants completed four open-ended questionnaires on their experiences learning mathematics through CAMI. The student teachers participated voluntary in the study and all the ethical requirements were met.

\section{Data Analysis}

The study is a case study qualitative research method using open-ended questionnaires for data collection for first-year teacher education students' self-directed learning. The qualitative research method approach described the first-year teacher education's self-directed learning through computer aided instruction. The face validity and the trustworthiness of the instruments were established. The questionnaires were analysed using descriptive data analysis.

\section{Results}

After the pilot study, reports were generated by CAMI for individual student teachers which are easily accessed by the lecturer. The figure below is a sampled generated report of a student teacher by the CAMI denoted by ST1. The Figure 2 Table from CAMI consist of: 
The date - date the student teacher did the exercise.

The exercise - the type of exercise that was done by the student teacher.

Cor - the scores of correct answers by the student.

Tot - total scores in a particular item

$\%$ - scores in percentage.

P.I - performance index

Time - the duration in which the student teacher used to finish the exercise.

\begin{tabular}{|c|c|c|c|c|c|c|}
\hline Date & Exercise & Cor & Tot & $\%$ & P.I. & Time \\
\hline $\begin{array}{l}8 / 1 / 2019 \\
01: 01: 54\end{array}$ & $\begin{array}{l}\text { 10.3.5.1 :Data and Statistics, Probability, Probability } \\
\text { models, Product rule for independent events [11.6, } \\
12.10]\end{array}$ & 2 & 2 & 100 & 1,4 & $00: 01: 23$ \\
\hline $\begin{array}{l}8 / 1 / 2019 \\
12: 15: 18\end{array}$ & $\begin{array}{l}\text { 10.3.4.1: Data and Statistics, Probability, Probability } \\
\text { models, Venn diagrams and set notation }[10.6,11.6]\end{array}$ & 6 & 6 & 100 & 4 & $00: 01: 30$ \\
\hline $\begin{array}{l}8 / 1 / 2019 \\
12: 30: 49\end{array}$ & $\begin{array}{l}\text { 10.3.4.3 :Data and Statistics, Probability, Probability } \\
\text { models, Complete Venn diagrams [11.6] }\end{array}$ & 2 & 2 & 100 & 0,8 & $00: 02: 40$ \\
\hline $\begin{array}{l}8 / 1 / 2019 \\
12: 35: 02\end{array}$ & $\begin{array}{l}\text { 10.3.4.5 :Data and Statistics, Probability, Probability } \\
\text { models. Complete Venn diagrams [11.6] }\end{array}$ & 4 & 4 & 100 & 0,9 & $00: 04: 13$ \\
\hline $\begin{array}{l}8 / 1 / 2019 \\
12: 39: 43\end{array}$ & $\begin{array}{l}\text { 10.3.4.6 :Data and Statistics, Probability, Probability } \\
\text { models, Mutually exclusive events [10.6, 11.6, } \\
12.10]\end{array}$ & 4 & 4 & 100 & 0,9 & $00: 04: 41$ \\
\hline $\begin{array}{l}\text { 8/1/2019 } \\
12: 53: 54\end{array}$ & $\begin{array}{l}\text { 10.3.4.7 :Data and Statistics, Probability, Probability } \\
\text { models, Product rule for independent events [11.6, } \\
12.10]\end{array}$ & 4 & 4 & 100 & 0,6 & $00: 06: 51$ \\
\hline $\begin{array}{l}7 / 31 / 2019 \\
04: 15: 39\end{array}$ & $\begin{array}{l}\text { 10.3.3.2 :Data and Statistics, Probability, Probability } \\
\text { models, Contingency tables with numbers }[9.5 .4 \text {, } \\
10.6,11.6]\end{array}$ & 9 & 10 & 90 & 2,1 & $00: 04: 20$ \\
\hline $\begin{array}{l}7 / 31 / 2019 \\
04: 49: 14\end{array}$ & $\begin{array}{l}\text { 10.3.3.3 :Data and Statistics, Probability, Probability } \\
\text { models, Contingency tables representing probability } \\
\text { [11.6] }\end{array}$ & 9 & 10 & 90 & 0,8 & $00: 11: 56$ \\
\hline $\begin{array}{l}8 / 1 / 2019 \\
12: 23: 01\end{array}$ & $\begin{array}{l}\text { 10.3.4.2 :Data and Statistics, Probability, Probability } \\
\text { models, Venn diagrams and advanced notation } \\
{[10.6,11.6]}\end{array}$ & 7 & 8 & 87,5 & 0,9 & $00: 07: 43$ \\
\hline $\begin{array}{l}8 / 1 / 2019 \\
01: 00: 31\end{array}$ & $\begin{array}{l}\text { 10.3.4.8: Data and Statistics, Probability, Probability } \\
\text { models, Product rule for independent events [11.6, } \\
12.10]\end{array}$ & 5 & 6 & 83,3 & 0,8 & $00: 06: 37$ \\
\hline $\begin{array}{l}7 / 31 / 2019 \\
02: 52: 01\end{array}$ & $\begin{array}{l}\text { 10.3.1.1 : Data and Statistics, Probability, } \\
\text { Introduction to probability, Possible outcomes - } \\
\text { simple events }[4.5 .4,5.5 .4]\end{array}$ & 16 & 20 & 80 & 2,1 & $00: 07: 27$ \\
\hline $\begin{array}{l}7 / 31 / 2019 \\
03: 15: 16\end{array}$ & $\begin{array}{l}\text { 10.3.1.3: Data and Statistics, Probability, } \\
\text { Introduction to probability, Simple chance - likely, } \\
\text { unlikely or impossible [7.5.4] }\end{array}$ & 8 & 10 & 80 & 5,5 & $00: 01: 27$ \\
\hline $\begin{array}{l}8 / 1 / 2019 \\
12: 28: 08\end{array}$ & $\begin{array}{l}\text { 10.3.4.3 :Data and Statistics, Probability, Probability } \\
\text { models, Complete Venn diagrams [11.6] }\end{array}$ & 4 & 5 & 80 & 0,8 & $00: 05: 07$ \\
\hline Date & Exercise & Cor & Tot & $\%$ & P.I. & Time \\
\hline $\begin{array}{l}7 / 31 / 2019 \\
04: 11: 06\end{array}$ & $\begin{array}{l}\text { *10.3.3.2 :Data and Statistics, Probability, } \\
\text { Probability models, Contingency tables with } \\
\text { numbers }[9.5 .4,10.6,11.6]\end{array}$ & 30 & 40 & 75 & 1,4 & $00: 20: 54$ \\
\hline $\begin{array}{l}8 / 1 / 2019 \\
11: 51: 33\end{array}$ & $\begin{array}{l}\text { *10.3.4.1 :Data and Statistics, Probability, } \\
\text { Probability models, Venn diagrams and set notation } \\
{[10.6,11.6]}\end{array}$ & 15 & 20 & 75 & 2,9 & $00: 05: 13$ \\
\hline $\begin{array}{l}7 / 31 / 2019 \\
04: 28: 43\end{array}$ & $\begin{array}{l}\text { *10.3.3.3 :Data and Statistics, Probability, } \\
\text { Probability models, Contingency tables } \\
\text { representing probability [11.6] }\end{array}$ & 7 & 10 & 70 & 0,5 & 00:13:05 \\
\hline $\begin{array}{l}7 / 31 / 2019 \\
03: 13: 49\end{array}$ & $\begin{array}{l}\text { *10.3.1.2:Data and Statistics, Probability, } \\
\text { Introduction to probability, Possible outcomes - } \\
\text { composite events [5.5.4,6.5.4] }\end{array}$ & 8 & 13 & 61,5 & 0,4 & $00: 21: 48$ \\
\hline $\begin{array}{l}7 / 31 / 2019 \\
03: 50: 12\end{array}$ & $\begin{array}{l}\text { *10.3.3.1 :Data and Statistics, Probability, } \\
\text { Probability models, Introduction to tree diagrams } \\
{[9.5 .4]}\end{array}$ & 9 & 15 & 60 & 0,6 & $00: 14: 19$ \\
\hline $\begin{array}{l}7 / 31 / 2019 \\
03: 31: 27\end{array}$ & $\begin{array}{l}\text { Introduction to probability, Elementary probability } \\
{[7.5 .4 .8 .5 .4]}\end{array}$ & 10 & 17 & 58,8 & 0,8 & $00: 11: 53$ \\
\hline $\begin{array}{l}7 / 31 / 2019 \\
05: 08: 20\end{array}$ & $\begin{array}{l}* 10.3 .4 .1 \text { :Data and Statistics, Probability, Venn- } \\
\text { diagrams, Venn diagrams and set notation [10.6, } \\
11.6]\end{array}$ & 19 & 35 & 54,3 & 1,2 & $00: 16: 13$ \\
\hline $\begin{array}{l}7 / 31 / 2019 \\
03: 19: 34\end{array}$ & $\begin{array}{l}\text { Introduction to probability, Simple chance - } \\
\text { impossible to certain }[7.5 .4]\end{array}$ & 18 & 35 & 51,4 & 4,2 & $00: 04: 18$ \\
\hline $\begin{array}{l}8 / 1 / 2019 \\
12: 47: 03\end{array}$ & $\begin{array}{l}* * 10.3 .4 .7 \text { :Data and Statistics, Probability, } \\
\text { Probability models, Product rule for independent } \\
\text { events }[11.6,12.10]\end{array}$ & 3 & 7 & 42,9 & 0,4 & $00: 07: 21$ \\
\hline $\begin{array}{l}8 / 1 / 2019 \\
12: 13: 48\end{array}$ & $\begin{array}{l}* 10.3 .4 .2 \text { :Data and Statistics, Probability, } \\
\text { Probability models, Venn diagrams and advanced } \\
\text { notation }[10.6,11.6]\end{array}$ & 1 & 10 & 10 & 0 & $00: 22: 16$ \\
\hline $\begin{array}{l}7 / 31 / 2019 \\
04: 34: 05\end{array}$ & $\begin{array}{l}* \star 10.3 .3 .3: \text { Data and Statistics, Probability, } \\
\text { Probability models, Contingency tables } \\
\text { representing probability [11.6] }\end{array}$ & 0 & 2 & 0 & 0 & $00: 02: 23$ \\
\hline \multicolumn{2}{|r|}{ representing probability [1 } & 200 & 295 & 67.8 & 1 & $03: 25: 38$ \\
\hline
\end{tabular}

Figure 2. The report of a student teacher (ST1) generated by CAMI 
The report from Figure 2 shows the exercise done by student teacher 1 (ST1) on $31^{\text {st }}$ of July and $1^{\text {st }}$ of August 2019 respectively. The exercises for the two days were on Introduction of Probability and the Probability Model. The best percentage obtained was for the Probability Model; the student scored $100 \%$ in a time of 1 minute and 23 seconds. While the lowest percentage was for the same was where the student scored $0 \%$ in a time of 2 minutes and 23 seconds. The highest scored for Introduction to Probability was $80 \%$ and the lowest scores was 51.4 in a time of 4 minutes and 18 seconds, which is more than the time of the lowest score in the Probability Model. Table 1 shows the analysis distribution of the sample report for the exercise generated by CAMI.

Table 1. Analysis distribution of the sampled report for ST1 for the exercise generated by CAMI

\begin{tabular}{ll}
\hline Items & Distribution analysis \\
\hline Total number of questions done & 295 \\
Total number of exercises & 25 \\
Best percentage & $100 \%$ \\
Average percentage & $67.8 \%$ \\
Worst percentage & $0 \%$ \\
Grade - average percentage & $0 \%$ \\
Best P.I. & 6 \\
Average P.I. & 1 \\
Worst P.I. & 0 \\
Grade - average P.I. & 0 \\
Number of exercises below 60\% & 6 \\
Number of exercises from $60 \%$ to $80 \%$ & 5 \\
Number of exercises above $80 \%$ & 13
\end{tabular}

Table 1 shows the distribution analysis of the sampled report exercise for ST1. From the table, the best performance index (that is the questions correct per minute) was obtained was for the Probability Model where the student obtained a PI of 5.5 in a time of 1 minute and 27 seconds. The worst performance index was for the same where the student obtained a PI of 0 in a time of 2 minutes and 23 seconds. The student completed a total of 25 exercises over 205 minutes, scoring an average of $67.8 \%$. The CAMI system gives reports for each student teachers. The total number of questions done by each student teacher, with the correct number of answers done and the performance index, are valuable information for effective teaching.

\section{Responses from student teachers}

Immediately after the completion of the exercises on CAMI, the student teachers were given a response sheet to express their experiences using CAMI to learn Probability. The results of the study were as expected: motivation for learning; active learning strategy and learning activity; recognising learning ability; and recognizing inequalities in learning according to SDL skills development. Some of the students' responses are shown below:

\section{Motivation for learning}

The student teachers expressed that learning through CAMI motivates their learning mathematics. The following are some of their responses:

"I saw that probability is very easy when using technology and helps students study easy and quick. Activities on CAMI make student to be active and not become fatigue very early and the future learners can study easily on CAMI".

"I have experienced that CAMI can explain using the speed notes and improve your understanding".

"I enjoyed using CAMI since I do not need to write as I am using a computer. It was also enjoyable because I immediately get my grades after every question".

"I have learnt that using computer is very nice, but I wish I can get time to use it before I go to activities otherwise, I have learnt a lot". 
The responses of the student teachers reflect that using CAMI is enjoyable. That is, it assists them to practice mathematics on the computer and improve their learning. Therefore, the student teachers were motivated and encouraged to learn mathematics.

\section{Active learning strategy and Learning activity}

The student teachers discover the strategies to learn mathematics and some of the mathematics activities that are useful and can assist them in their teaching profession. Some of the student teachers responded these ways:

"I have experienced many ways on how probability is asked. I have the ways to answer it".

"Teaching me how to use computer so that I can use it when I am teaching at school. It is easy to learn probability and helping to use computer also a deal with probability".

"... It gives me more experience and I have learnt to answer question quickly. The more I use it, the more I learn".

"I have experienced that there are simple ways that can be used to teach mathematics and those ways are one very simple like CAMI, it guides you as you go on with your lesson". "I learn to solve difficult problems".

"I learnt more about how to deal with probability more especially on Venn Diagram, I also experience to deal with the counting principles. I felt so excited because I can face any challenging question on probability".

"I recommend CAMI a lot and I guess in future it will be used. I gained a lot of experience and skills to approach questions".

Learning through CAMI, the student teachers recognise strategies that are helpful to solve some difficult problems in teaching and learning mathematics. In addition, the student teachers acquired knowledge and skills on how questions are being asked and answered in mathematics especially in Probability which will be obligatory for their teaching practice. The student teachers were actively trained through CAMI.

\section{Recognising learning ability}

The student teachers identified individual learning ability using technology (CAMI) and the skills needed to improve on it. These are some of their responses:

"It makes my life easier in term of studying mathematics contents".

"Activities on CAMI make student to be active and not become fatigue very early and the future learners can study easily on CAMI".

"CAMI is a good app it is so helping it makes me learn first and upgrade my knowledge at an instant and for the fact that it is a technology thing it is enjoyable".

"I learned new things and I gain skill of using a computer on answering mathematics problems. It helps me to learn more in mathematics and it is easy to use it".

The student teachers recognize their learning ability using CAMI and how it can be improved. Hence, using CAMI helped the student teachers to reflect on what is being learnt and enhanced them to learn more.

\section{Recognising inequalities in learning}

The learning of mathematics helps the student teachers recognise the learning differences, that is, previous knowledge on computer literacy and the existing knowledge in Probability. Some of the student teachers' responses are stated below:

"At first, I was confused because I could not use that app and not that I am not familiar with a computer but because the app is much complicated that it should be for the first-year students. Now that I am used to it, it is much easier to use it and I noticed that this app saves a lot of time".

"Initially the program was a little bit trickly, but as time goes by, it became better and understandable".

"It was hard for the first time, but as I keep going there on CAMI lab, I got some notice from my ability to solve a problem. Using CAMI, it helped developing my mind and when I got exercise some problem, they get more easier".

"It makes probability to be easy since probability is a testing of knowledge because it wants you as a student to be a critically thinker".

From the response, the student teachers acknowledge the learning gaps. The student teachers reflect that practicing and consistency make them understand the mathematics concept. 
The student teachers' responses reveal that CAMI assisted the student teachers to develop self-directed learning skills. CAMI motivated the student teachers to learn mathematics and gain more strategies of learning as well as learning activities. In addition, through CAMI, the student teachers discovered their learning potentials and were able to identify differences in learning.

\section{Discussion}

This paper is built on mathematical knowledge for teaching (MKfT) of student teachers as acquired through self-directed learning (SDL) in an ICT enabled environment. The findings in Table 1 and Figure 2 show how the integration of technology (CAMI) enhances the effect on teaching of teacher educators. The results show a CAMI generated report for an individual student teacher which includes the time and date the participant embarked on the learning, as well as the period of time the student teacher used to learn a particular topic. The indication means the CAMI in this study is used to monitor students' learning, the time the learning takes place, and the performance of the student within the duration of time. CAMI is also used to evaluate the student performance in term of area of weaknesses. The integration of technology (CAMI) was a delightful experience for the educators (lecturers) in that the data and reports generated for the 230 students, at the click of a button, was time saving and useful with regard to what each student teacher learnt within timeframe.

CAMI is a supportive technology environment that enhances effective teaching. This result is in line with the suggestion of (Abas \& David, 2019) Abas and David that the academic community should be encouraged to create technology environments which are in support of effective teaching. The suggestion came up from the researchers' study results which revealed that the extent of competency levels and positive impact in using technology on students' behaviour in the teaching-learning process were very high. In addition, (Leung, 2017) Leung asserts that for teachers to be capable in the use of technological instruments, and any subject matter knowledge, effective learning is required.

From the responses, all the student teachers (100\%) liked using CAMI as the technology has improved their understanding of concepts in Probability and developed their skills in computer aided learning. It has created confidence and they enjoyed the new technology assisted approach. The responses also reveal the skills that characterized self-directed learning. There was active learning where the student teachers were more engaged in learning activities and able to solve mathematics problems without any assistance from the educators. The student teachers were motivated to learn more and to solve difficult problems in mathematics (Probability). Learning through CAMI increased the student teachers' critical thinking; enhanced the understanding in Probability, reflection of the previous learning occurred; and focused the student teachers. This finding is line with (De Beer \& Gravett, 2016) the notion that self-directed learning builds up existing mathematical knowledge and engages student teachers more in active learning to teach, more than developing information to teach, rendering them better able to engage in authentic practical mathematics tasks. Furthermore, the student teachers had opportunities to reflect on what was learnt and used formative assessments whilst providing constructive feedback regarding the learning progress (De Beer \& Gravett, 2016). These results also concurred with the study of (Makonye, 2016) (Jordaan \& Havenga, 2020; Kruger, 2020) and (Bailey \& Lubbe, 2020) where all concluded that the promotion of SDL in HEIs will enable the student teachers to solve mathematics problems actively and effectively.

From the results, the student teachers demonstrated the three teachers' knowledge domains within the subject matter knowledge: common content knowledge (CCK), horizon content knowledge (HCK), and specialised content knowledge (SCK). Learning through CAMI was an additional support in acquiring mathematical knowledge that student teachers need to know to be able to do to come up with meaningful teaching methods as proposed by (Ball, Thames \& Phelps, 2008). The student teachers developed knowledge of a specific mathematical procedure (Probability) to be used in teaching.

\section{Conclusions and Recommendation}

The reports from CAMI shed light on the immense possibilities of analyzing student teachers' performance on a given topic executed through self-directed learning in an ICT integrated environment. The responses from student teachers suggest that technology has improved their understanding of concepts in Probability and developed their skills in self-directed learning and in computer-aided learning. It has created confidence and they enjoyed learning through this new technology assisted approach. The experience has improved the academic performance and professional competence of the student teachers as well as enhanced effective learning of mathematics. CAMI influences first-year teacher education students' self-directed learning evidenced by motivation in learning, active learning strategies and activities, recognizing learning ability and inequalities in learning. The student teachers were encouraged to be more active in teaching and learning mathematics. 
The study recommends technology integration in teaching and learning in the HEIs, especially in the teacher education faculties, to promote self-directed and to support effective learning which will be useful and delivered to the future learners. It also recommends creation of self-directed environments which have a positive impact to foster mathematics teaching and learning in this era of a technology-driven world.

\section{Limitation}

This study is only open to first-year mathematics teacher education students. The student teachers were only exposed to CAMI, technology-based learning; there was no involvement of other groups as well as no consideration of traditional teaching and learning processes. Further research should be done with higher level mathematics students; and on the combination of self-directed and self-efficacy, as well as involvement of other groups, to compare traditional and technology-based teaching and learning processes.

\section{References}

Abas, M., \& David, A. (2019). Teachers' self-assessment towards technology integration in teaching mathematics. International journal for cross-disciplinary subjects in education, 10(2), 4068-4079. https://doi.org/10.20533/ijcdse.2042.6364.2019.0496

Alex, J. K. (2019a). The Preparation of Secondary School Mathematics Teachers in South Africa: Prospective Teachers' Student Level Disciplinary Content Knowledge. EURASIA Journal of Mathematics, Science and Technology Education, 2019a, 15(12). https://doi.org/10.29333/ejmste/105782

Alex, J. K. (2019b). Transforming mathematics learning through Computer Aided Mathematics Instruction. 46th Annual conference of the Southern African Society for Education, East London .2019b. 25-27 September 2019.

Bagheri, M., Ali, W. Z. W., Abdullah, M. C. B., \& Daud, S. M. (2013). Effects of project-based learning strategy on self-directed learning skills of educational technology students. Contemporary Educational Technology, 4(1), 15-29. https://doi.org/10.30935/cedtech/6089

Bailey, R., \& Lubbe, E. (2020). Blending and cooperating in the computer literacy classroom: An opportunity to develop self-directed learning skills. In J. Olivier (ed.), Self-directed multimodal learning in higher education. Cape town: AOSIS; 2020; 5, 343-372. https://doi.org/10.4102/aosis.2020.BK210.10

Ball, D. L. (2000). Bridging practices intertwining content and pedagogy in teaching and learning to teach. Journal of Teacher Education, 51(3), 241-247. https://doi.org/10.1177/0022487100051003013

Ball, D. L., Thames, M. H., \& Phelps, G. (2008). Content knowledge for teaching: What makes it special. Journal of teacher education, 59(5), 389-407. https://doi.org/10.1177/0022487108324554

Ben-Eliyahu, A., \& Linnenbrink-Garcia, L. (2015). Integrating the regulation of affect, behavior, and cognition into self-regulated learning paradigms among secondary and post-secondary students. Metacognition Learning, 10, 15-42 https://doi.org/10.1007/s11409-014-9129-8

Bishara, S. (2021). The cultivation of self-directed learning in teaching mathematics. World Journal on Educational Technology: Current Issues, 13(1), 82-95. https://doi.org/10.18844/wjet.v13i1.5401

Bray, A., \& Tangney, B. (2017). Technology usage in mathematics education research-A systematic review of recent trends. Computers \& Education, 114, 255-273. https://doi.org/10.1016/j.compedu.2017.07.004

Callaghan, M. N., Long, J. J., Van Es, E. A., Reich, S. M., \& Rutherford, T. (2018). How teachers integrate a math computer game: Professional development use, teaching practices, and student achievement. Journal of Computer Assisted Learning, 34(1), 10-19. https://doi.org/10.1111/jcal.12209

De Beer, J., \& Gravett, S. (2016). The affordances of case-based teaching for self-directed learning: A case study with first year student-teachers, in E. Mentz \& I. Oosthuizen (eds.), Self-directed learning research, (pp. 35-71). AOSIS. https://doi.org/10.4102/aosis.2016.sdlr14.02

Du Toit-Brits, C. (2020). Unleashing the power of self-directed learning: criteria for structuring self-directed learning within the learning environments of higher education institutions. Africa Education Review, 2020 Mar 1, 17(2), 20-32. https://doi.org/10.1080/18146627.2018.1494507

Garrison, D. R. (1997). Self-Directed Learning: Toward a comprehensive model. Adult Education Quarterly. November 1997. https://doi.org/10.1177/074171369704800103 
Hill, H. C., Blunk, M. L., Charalambous, C. Y., Lewis, J. M., Phelps, G. C., Sleep, L., \& Ball, D. L. (2008). Mathematical knowledge for teaching and the mathematical quality of instruction: An exploratory study. Cognition and instruction, 26(4), 430-511. https://doi.org/10.1080/07370000802177235

Jacinto, E. L., \& Jakobsen, A. (2020). Mathematical knowledge for teaching: how do primary pre-service teachers in Malawi understand it? African journal of research in mathematics, science, and technology education, 24(1), 31-40. https://doi.org/10.1080/18117295.2020.1735673

Jordaan, T., \& Havenga, M. (2020). University-school initiative for a career in engineering: development of self-directed learning when solving mathematics problems. World Transactions on Engineering and Technology Education, 18(3). http://www.wiete.com.au/journals/WTE\&TE/pdf

Kruger, D. (2020) Adaptive learning technology to enhance self-directed learning', in J. Olivier (ed.), Self-directed multimodal learning in higher education. Cape town: AOSIS; 2020; 5, 93-116. https://doi.org/10.4102/aosis.2020.BK210.03

Leung, A. (2018). Exploring Techno-Pedagogic Task Design in the Mathematics Classroom Boundary object. 2018; October. https://doi.org/10.1007/978-3-319-43423

Makonye, J. P. (2016). The enactment of problem-based approaches in pre-service mathematics and the levels of performance of teacher students in problem projects. In E. Mentz \& I. Oosthuizen (eds.), Self-directed learning research. Cape town: AOSIS; 2016, 184-212. https://doi.org/10.4102/aosis.2016.sdlr14.07

Mthethwa, L. C. (2018). Computer-based tutoring role in Inducting the first year's students at a previously disadvantaged university. Gender and Behaviour, $11452-11464$. https://journals.co.za/doi/pdf/10.10520/EJC-131e6a8135

Pasley, J. D. (2011). Perspectives on deepening teachers' mathematics and science content knowledge, MSP knowledge management and dissemination. Horizon Research, Inc. 2011. http://www.mspkmd.net/cases/tck/perspectives/introduction.pdf

Saylan, A., Onal, N. T., \& Onal, N. (2018). Using Technology in Education from the Pre-service Science and Mathematics Teachers' Perspectives. International Education Studies, 11(10), $28-41$. https://doi.org/10.5539/ies.v11n10p28

Sekano, K. G. (2020). Enhancing Mathematics teachers' Self-Directed Learning through Technology-Supported Cooperative Learning. [Doctoral dissertation] North-West University, South Africa, 2020.

Shulman, L. S. (1986). Those Who Understand: Knowledge Growth in Teaching. Educational Researcher, 15(2), 4-14. https://doi.org/10.3102/0013189X015002004

Van der Walt, H. (2016). The feasibility of grafting self-directed learning theory onto capability theory. In E. Mentz \& I. Oosthuizen (eds.), Self-directed learning research. Cape town: AOSIS; 2016. p.1-34. http://doi.org/10.4102/aosis.2016.sdlr14.01

Viberg, O., Grönlund, A., \& Andersson, A. (2020). Integrating digital technology in mathematics education: a Swedish case study. Interactive Learning Environments, 1-12. https://doi.org/10.1080/10494820.2020.1770801

\section{Copyrights}

Copyright for this article is retained by the author(s), with first publication rights granted to the journal.

This is an open-access article distributed under the terms and conditions of the Creative Commons Attribution license (http://creativecommons.org/licenses/by/4.0/). 